\title{
REHABILITACION DE SUELOS HORTÍCOLAS: IMPACTO DE PRÁCTICAS AGRÍCOLAS CON USO DE YESO Y DRENAJE
}

\author{
Muguiro, A. ${ }^{1 ;}$ Álvarez, C. ${ }^{1} ;$ Babinec, F. $^{2}$ \& Marano, R. ${ }^{3}$
}

\begin{abstract}
RESUMEN
El exceso de $\mathrm{Na}^{+}$, carbonatos y bicarbonatos presentes en el agua de riego incrementan el $\mathrm{pH}$, la conductividad eléctrica (CE) y el porcentaje de sodio intercambiable (PSI), afectando el crecimiento de los cultivos. El objetivo de este trabajo fue cuantificar el impacto de prácticas de manejo con aplicación de yeso y drenaje en suelos petrocálcicos de La Pampa afectados por riego con aguas subterráneas bicarbonatadas sódicas. Se cultivó lechuga durante cuatro ciclos (500 días) en dos invernáculos diferenciados por la cantidad previa de años de riego, utilizando un diseño factorial completamente aleatorizado con 4 submuestras (unidades de medición). Los tratamientos en ambos túneles ( 2 años=B1 y 4 años=B2) fueron: 1) T0, testigo sin tratar; 2) T1, 3,5 Mg ha-1 de yeso agrícola, 3) $\mathrm{T} 2,3,5 \mathrm{Mg} \mathrm{ha}^{-1}$ de yeso agrícola + drenaje y 4) T3, drenaje. La incorporación de yeso disminuyó la concentración de $\mathrm{Na}^{+}$y PSI significativamente desde superficie hasta 0,4 m. También mejoró significativamente las condiciones físicas del suelo en el túnel B2, aspecto que se manifestó con un incremento de la productividad acumulada del cultivo de lechuga. En cambio no se encontraron diferencias significativas en el $\mathrm{pH}$ del suelo en ninguna de las profundidades evaluadas. Adicionalmente, la $\mathrm{CE}$ del suelo con los diferentes tratamientos disminuyó notablemente a partir del $2^{\circ}$ ciclo de producción debido al incremento en la dosis de riego.
\end{abstract}

Palabras clave: riego por goteo, lechuga, enmiendas, drenaje.

1.- AER Gral. Pico. (6360) General Pico, provincia de La Pampa. Email: muguiro.alberto@inta.gob.ar 2.- EEA INTA Anguil. (6326). Anguil, provincia de La Pampa.

3.- Facultad de Ciencias Agrarias (UNL). Kreder 2805. (3080) Esperanza, provincia de Santa Fe.

Manuscrito recibido el 30 de noviemrbe de 2016 y aceptado para su publicación el 14 de marzo de 2017. 
A. Muguiro et al.

\begin{abstract}
Soils with physical impediments and horticultural crops: impact of agricultural management with gypsum and drainage.

The excess of $\mathrm{Na}^{+}$, carbonates and bicarbonates present in irrigation water increases the $\mathrm{pH}$, the electric conductivity (EC) and the exchangeable sodium percentage (ESP) in the soil, thus affecting crop growth. The aim of this work was to quantify the use of different techniques in petro-calcium soils of La Pampa affected by irrigation with sodium bicarbonate underground waters. Lettuce was grown during four cycles (500 days) in two greenhouses differentiated by years of irrigation, using a completely randomized factorial design with 4 sub-samples (units of measurement). Treatments in both tunnels ( $2=\mathrm{B} 1$ and 4=B2 years) were: 1) T0, non-treated control; 2) $\mathrm{T} 1,3.5 \mathrm{Mg} \mathrm{ha}^{-1} \mathrm{of}^{-}$ agricultural gypsum, 3) T2, $3.5 \mathrm{Mg} \mathrm{ha}^{-1}$ of agricultural gypsum + drainage, and 4) T3, drainage. Gypsum significantly decreased the concentration of $\mathrm{Na}^{+}$and ESP from the surface to $0.4 \mathrm{~m}$. It also significantly improved the physical conditions of the soil in tunnel B2, which was manifested through an increase of the accumulated productivity of the lettuce crop. However, no significant differences were registered in soil $\mathrm{pH}$ in any of the evaluated depths. Additionally, the soil EC under the different treatments decreased notably from the 2 nd production cycle onwards, due to the increase in the irrigation depth.
\end{abstract}

Key words: drip irrigation, lettuce, amendment, drainage.

\section{INTRODUCCIÓN}

La producción de hortalizas en invernáculo ha tenido un amplio crecimiento en el mundo y especialmente en nuestro país (26). En La Pampa la producción de lechuga (Lactuca. sativa var. crispa o intybacea L) es una alternativa para pequeños productores hortícolas, la cual comenzó a tomar importancia en el año 2000.

En los últimos 10 años los suelos de esta región bajo cubierta plástica muestran una tendencia a la degradación debido a los sucesivos ciclos de horticultura intensiva. La misma se manifiesta en sus propiedades físicas y químicas, materia orgánica, actividad microbiológica, disminución de la estabilidad estructural, menor capacidad de infiltración, mayor necesidad de fertilizantes e incremento de los problemas de halomorfis- mo (43). Las causas se deben tanto a la calidad del agua de irrigación como al método utilizado, debido a que el riego por goteo se aplica en pequeñas dosis que no tienen en cuenta los requerimientos de lixiviación. Por otra parte, al tener cobertura plástica durante varios años, las precipitaciones son insuficientes para permitir un adecuado drenaje de las sales acumuladas en el perfil.

El exceso de cationes como el $\mathrm{Na}^{+}$y aniones como $\mathrm{CO}_{3}^{2-}$ y $\mathrm{HCO}_{3}^{-}$, presentes en el agua de riego, incrementan el $\mathrm{pH}$ del suelo, la conductividad eléctrica del extracto de saturación (CEe), el porcentaje de sodio intercambiable (PSI) y por ende se afecta el crecimiento de los cultivos (20). En la medida que el $\mathrm{Na}^{+}$sustituye al $\mathrm{Ca}^{2+}$ en el complejo de intercambio, el suelo reduce la permeabilidad y algunos cultivos sensibles pueden manifestar síntomas de intoxicación 